\title{
INNOVATIVE SUPPLIER PARTNERSHIP ASSESSMENT MODEL IN A POLISH TRADING ENTERPRISE
}

\author{
Rafał Tyszkiewicz, Agnieszka Pawlak-Wolanin, \\ Julita Markiewicz-Patkowska, Soňa Jandová, Piotr Oleśniewicz, \\ Helena Jáčová, Monika Tyszkiewicz
}

\section{Introduction}

The relationship between a company and a supplier is a strategic resource for both parties. However, not every such relationship can be considered strategic. In order for a relationship to assume strategic importance, it must be special (or unique) in some terms and difficult to imitate. Otherwise, it will not contribute to making the company stand out against the competition. Such relationships may be formed in two areas. Firstly, they may be intended to increase the company's access to financial resources; secondly, they facilitate investment (Tyszkiewicz, 2017b).

It is noteworthy that partnership is based on such elements as trust and communication. These factors produce a continuous and deepening effect to ensure long-term results satisfactory for both parties involved.

It is also significant to define the roles, tasks, and responsibilities of the suppliers and the clients, as well as to fairly share risks, costs, and profits arising from implementation of new initiatives (Christopher, 2000).

The development of a supplier partnership assessment model is one of the efforts channelled into continuous development of a company. The analysis of an enterprise presented in this article indicates the directions of such efforts, paying particular attention to selecting the right criteria and assessment methods, defining the optimal significance of the criteria, as well as the categories of suppliers, and interpreting the obtained results. The proposed model allows to carry out an assessment of the potential and existing suppliers and eventually make a choice based on their capacity to supply goods consistent with the company's requirements.
The aim of the model is to systematize knowledge and the reasoning of managers in the company in terms of planning, organization, and implementation of joint actions intended to foster partnership with the company's suppliers. The model suggests and the self-assessment methodology verifies whether such assessment of partnership with the suppliers is carried out effectively.

The assessment and selection of the suppliers took place in stages. In stage 1, basic supplier assessment criteria, which were considered key by the company, were laid down. Altogether, four main criteria were adopted: price, delivery time, quality of materials, and additional features. These criteria were extended by an array of extra features of the greatest significance to the company. After establishing the supplier assessment criteria, the following were performed:

- Scoring was based on the arithmetic mean and the weighted average. Two scoring methods were adopted. The first method consists in awarding points every second value, starting from zero. There is no fixed scale. In turn, a scale from only one to five was accepted for the second method, ascending by 1 point in the case of a parameter with only two options. The maximum number of points (i.e., 5 points) is awarded for the best option and the smallest for the worst option.

- A graphic method was adopted, which consists in presenting suppliers on a radar chart where the weaknesses and strengths of each are clearly presented.

- The Analytic Hierarchy Process (AHP) method was adopted with measurable criteria exclusively. Verbally and subjectively evaluated criteria were not taken into 
consideration so that accuracy of the analysis could be enhanced.

\section{Literature Review}

Nowadays, building partner relationships with suppliers is a widely discussed topic since it is the source of an array of benefits, such as (Urbaniak, 2008):

- time-saving;

- risk mitigation related to selecting a new supplier or purchasing a new product (brand);

- quicker and more effective flow of market information;

- joint organizational and technical problemsolving.

Building sustainable partnerships between companies assumes particular importance in times of fierce global competition. Globalization is one of the key causes of increasing market uncertainty that prompts companies to accelerate interaction with external partners (Lorenzoni \& Lipparini, 1999).

One of the pillars of value management in the global network economy is managing relations between companies. On the supply side in value networks, the management of suppliers of key importance for the delivered value gains a strategic role. Companies strive to develop optimal supplier bases, both in terms of quantity, i.e. the number of suppliers in individual locations, as well as in terms of quality, in order to achieve synergy effects (Ocicka \& Raźniewska, 2015).

Managing relations with suppliers is also important for supply chain and logistic processes management, quality management, risk management, and innovation management (Van Weele, 2014).

Applying the idea of managing relations with suppliers gives the company new opportunities to shape competitiveness. Therefore, the process of shaping partnership relations with suppliers is important for the creation of a competitive enterprise system. In this process, relations with suppliers play an important role, as suppliers are necessary entities for the company, and their influence on shaping its competitiveness is expressed primarily in creating the quality and price of the final product (Tyszkiewicz, 2017a).

Generating values expected by customers allows realizing values for the benefit of the company. This may manifest itself in achieving a profitability of product sales higher than competition, profitability of customers, or a larger market share, as well as in gaining a competitive advantage (Matwiejczuk, 2014).

In search of the competitive edge arising from partner cooperation, the main causes of failure are (Christopher, 2000):

- lack of permanent mutual trust;

- no partner involvement in cooperation;

- changes on the market;

- projects lasting for too long;

- seeing the partner as a potential competitor.

The motives for which companies establish and maintain partnership relations are primarily the necessity (meeting legal or contractual requirements), asymmetry (reaction to pressure, e.g. of another organization), reciprocity (introducing cooperation and coordination), efficiency (improvement of internal effectiveness), stability (increasing the adaptive response to environmental uncertainty), and justness (reaching an agreement with common norms, principles or expectations of the environment, as well as improving the image, reputation, and prestige) (Bouchbout \& Alimazighi, 2009).

Besides that partnership is concerned with taking joint actions in terms of identifying and limiting risks related to the jointly managed flows of goods and information in the supply chain (Wieteska, 2011).

Cooperation between a company and a supplier has a major impact on gaining competitive advantage through sharing information and joint decision-making, as well as through relationships between the organizations. Regardless of business type, in order for any company to become competitive, it needs to surpass other companies in numerous relationships in its environment. The relationships may take up different forms: from simple incidental transactions through long-term partnerships to integrated advanced organizational structures (Kaczmarek, 2011; Kale \& Singh, 2009; Provan \& Kenis, 2007).

Interorganizational cooperation should be studied as two independent phenomena, despite the existing relationships between the two organizations (Smith, Carroll, \& Ashford, 1995). It is also demonstrated Ashkenas, Ulrich, Jick, and Kerr (1995), who discuss how organizations can overcome barriers to internal and external cooperation. 
Tab. 1: Differences between the traditional and partnership approaches to suppliers

\begin{tabular}{l|l|l}
\multicolumn{1}{c|}{ Aspect } & \multicolumn{2}{c}{ Approach } \\
\hline Criterion & Traditional buying & Partnership with suppliers \\
\hline $\begin{array}{l}\text { Basis of the supplier-customer } \\
\text { relationship }\end{array}$ & With a high mistrust level & Mutual trust \\
\hline Role of supplier & Frequently an opponent & Cooperating partner \\
\hline Relationship duration & Often very short & Relatively long \\
\hline Supply quality criteria & Compliance with specifications & $\begin{array}{l}\text { Preferred customer requirements } \\
\text { and legal regulations }\end{array}$ \\
\hline $\begin{array}{l}\text { Methods of ensuring quality } \\
\text { of supplies }\end{array}$ & Verification of compliance & $\begin{array}{l}\text { Systemic approach based } \\
\text { on prevention }\end{array}$ \\
\hline Communication with suppliers & $\begin{array}{l}\text { Frequently formal, focused } \\
\text { on agreements and regulations }\end{array}$ & $\begin{array}{l}\text { Systematic, based on best } \\
\text { practice exchange }\end{array}$ \\
\hline Base of suppliers & Numerous suppliers & $\begin{array}{l}\text { Suppliers reduced in number but } \\
\text { carefully selected }\end{array}$ \\
\hline $\begin{array}{l}\text { Strategies of supplier } \\
\text { approach }\end{array}$ & $\begin{array}{l}\text { Information (data) from warranty } \\
\text { repair departments }\end{array}$ & $\begin{array}{l}\text { Resulting from process and } \\
\text { relationship management }\end{array}$ \\
\hline $\begin{array}{l}\text { Main criteria for making } \\
\text { decisions on the part } \\
\text { of the recipient }\end{array}$ & Often only delivery prices & Full purchase costs \\
\hline Key to a successful purchase & Recipient's ability to negotiate & $\begin{array}{l}\text { Partners' ability to search for } \\
\text { opportunities to improve }\end{array}$ \\
\hline Purchase plans & $\begin{array}{l}\text { Created primarily to meet the } \\
\text { needs of customers }\end{array}$ & $\begin{array}{l}\text { Integrated, with the consideration } \\
\text { of end-users }\end{array}$ \\
\hline Emphasis on quality & Supply & Relationships \\
\hline
\end{tabular}

Source: Nenadál (2006, p. 22)

The traditional approach to customersupplier relations is based on maintaining a certain distance between the parties. Now, instead of this approach, it is suggested that companies try to build wider business relationships, supporting each other's development. This is possible when the supplier has a general orientation in the needs of the customer (and vice versa). The relational approach is characterized by stronger ties between the partners. In these circumstances, the supplier's objective is to engage in the development of the customer's business, in the increase of the return on investment, and in supporting competitiveness (Tab. 1).

As time passes, the relationship strengthens and becomes more and more individualized, which may consist in (Romanowska \& Trocki, 2002):

- the supplier taking a specific and exceptional approach to the client;
- maximally adjusting production or processes to the receiver's needs;

- eliminating errors in sales cooperation;

- developing a friendly approach towards the receiver;

- adjusting solutions so that they suit the client although not always the company;

- personalizing the approach to the client;

- sending informative signals testifying to a clearly personalized character.

It is thus worth fostering the relationships that take care of developing the capital of partnership and relationship and within the framework of these relationships, special importance should be attached to the following: trust, involvement, balancing mutual interrelations, and effective conflict management (Laskowska-Rutkowska, 2014).

Cooperation based on the principle of partnership may be supported with the 
implementation of the concept of Supplier Relationships Management (SRM). This concept in turn draws support from IT systems dedicated to the business process in question. Purchase management is usually closely linked to other business divisions of the company and forms an integral part of the operational strategies of each of these business areas (Ross, 2018). According to Poirer (2012), SRM first and foremost focuses on building the relationship between the purchaser and the key suppliers while striving for identification of the possibilities that foster further development of their relationship, mutual improvement, and increase in benefits of both partners operating in a networked business environment.

The main aim of SRM is to develop twoway, mutually beneficial relationships with strategic suppliers (Mettler \& Rohner, 2009). In the model of the Global Supply Chain Forum, SRM was defined as a processes focused on fostering relationships with suppliers, created together by employees representing various business functions in a company, and influencing the value delivered to the clients and other stakeholders (Lambert \& Pohlen, 2001). This refers to the whole life cycle of a contract so that maximum participation of the supplier in achieving strategic goals of the receiver can be ensured (Emmett \& Crocker, 2009). It is a set of methods and practices that are needed in the course of interactions with the suppliers of goods and services that carry different importance for the profitability of the receiver (Poirer, 2012). Moreover, it testifies to the evolution of the approach to supply chains from management of purchases and deliveries to management of suppliers (Emmett, 2012).

\section{Methodology}

Formulating the article objective has led to putting forward three hypotheses:

- H1: Selection of a supplier is based on scoring used in supplier partnership assessment.

- H2: Supplier selection is accompanied by the analysis and comparison of offers. Comparison is carried out by way of scoring or on the basis of indicators.

- H3: Owing to varied and complex calculation methodology, the adopted supplier selection methods produce highly authoritative results.
Adopting two methods, one based on the arithmetic mean and the other on weighted average, has allowed to confirm and accept the above hypotheses as valid. Data presented in Tabs. 5-9 indicate that the results obtained with the arithmetic mean and with the weighted average were different. In supplier scoring, the most important criterion for selecting potential suppliers based on the criterion of price is the feature of price in comparison with the competition, whereas for the criterion of delivery time it is the feature of in-transit lead time.

Confirming empirically that with increasing numbers of dynamic capabilities, the partnership success rate diminishes, but then confirming that formal and/or informal safeguards influence this relationship positively, would be a very valuable insight for a technology innovative subject-matter expert (SME) wishing to partner or already partnering with a large company.

Operational data of a company and data derived from the relevant literature served to carry out comprehensive assessment of the supplier selection process. The assessment and selection of the key suppliers took place through the use of the following methods: $A B C$ analysis, scoring (as described in section 3.1), the graphics method, and the AHP method.

Many more documents apply AHP for supplier selection. Considering the uncertain environment in supply chain management, numerous literature positions referred to AHP methods combined with the fuzzy theory in supplier selection (Wen, Yan, Xian, Yue, \& Peng, 2015).

The verification of the hypotheses and the formulated assessment criteria was performed on the basis of a Polish company, Centrum Projekcji Multimedialnych (CPM). The company under examination cooperates with several suppliers who offer, among other things, parts for audio-visual systems or sound and image distribution systems. Frequently, clients themselves make the company choose components from a particular supplier.

CPM is a team of experts who, for more than ten years, have been delivering comprehensive multimedia solutions, such as: control systems, audio-video systems, sound and image distribution systems, television, and intelligent building systems. The team integrates systems and devices for the maximum functionality, usefulness, and comfort of use. 
The company's services have been used by around 500 clients from various business areas, including educational facilities, and (local) government organizations, e.g. Agora S.A., Campina Polska, Carlsberg Okocim S.A., Dinners Club Polska, Europejski Fundusz Leasingowy S.A., Sony Poland, NESTLE Waters Polska S.A.

\section{Research Results}

Below are presented the results of the research performed in cooperation with the CPM company.

\subsection{Supplier Selection Methods}

When selecting a supplier, one should consider whether it is a permanent supplier, what number of suppliers can provide the same goods, and what the supplier's transport capabilities are. To this end, offers are analysed and compared on the basis of scoring or indices (Kawa, 2011). Scoring consists in:

- establishing the crucial selection criteria, including appropriate features;

- establishing the rank of features;

- setting a scoring scale;

- introducing possible weights;

- summing up the total number of points obtained by each supplier;

- selecting the supplier.

As far as scoring is concerned, features of quality are scored as follows: 5 points - highest quality, 4 points - quality slightly above minimum requirements, 3 points - quality meeting minimum requirements, 2 points - quality below the minimum level, 1 point - quality not meeting minimum requirements.

Price scoring (scoring II), in turn, takes the following form: 5 points - a supplier offering prices more than $5 \%$ lower than average, 4 points - up to $5 \%$ lower than average, etc., 1 point - price more than $5 \%$ higher than average (Tab. 3 ).

The method using indices consists in comparing particular indices, such as:

- the number of successful deliveries to a number of placed orders;

- the number of successful deliveries to the total number of deliveries;

- the number of delayed deliveries to the total number of deliveries;

- the number of complaints with respect to deliveries to the total number of deliveries;

- frequency of erroneous deliveries.

\subsection{Supplier Selection Criteria in a Company}

Supplier selection criteria are varied. Generally, minimization of the costs of purchase and storage of stock should be the priority; uninterrupted supply and production processes should be simultaneously ensured. The most important and costly element of a transaction is considered to be the price of goods where the requirements regarding quality are satisfied. The supplier should be assessed in respect of their finances since low prices may be a symptom that the supplier will soon be facing bankruptcy.

Furthermore, sale conditions are integrally related to the price as they determine which party bears the costs of transport and parcel insurance. Other important aspects include: the conditions of delivery, guarantees and acknowledgement of claims, the financial situation, opinion among other receivers, capability of adapting to the changes in demand, localization, and communication system (Kawa, 2011).

Four main criteria were adopted in the supplier partnership assessment model: price, delivery time, quality of materials, and additional features that are most important for a company (e.g. the supplier keeping stock, the supplier's potential, and the supplier's image). The properties are provided in Tab. 2.

Owing to the fact that suppliers of different components are subject to assessment, it is not possible to base comparison solely on the value of the price, hence the indicator of price level in comparison with the competition has been adopted. It is a percentage value reflecting the price offered by a supplier in relation to the average price (the arithmetic mean) on the market of the supplier. Supply crediting is also a significant feature. The longer the payment deadline, the better it is for the company's liquidity since it allows to obtain the amount due from the client and pay for the goods. In-transit lead time comprises the stages of: placing the order, preparation, and appropriate transport. Delivery timeliness is measured as the probability of meeting the established delivery deadlines and delivery of goods as ordered.

Another parameter is readiness to carry out delivery on conditions specified by the client. Two options are possible: the supplier imposes their own delivery schedule or inclines 


\section{Business Administration and Management}

\section{Tab. 2: Supplier assessment criteria}

\begin{tabular}{c|c|l}
\multicolumn{1}{c|}{ Criterion } & $\begin{array}{c}\text { Criterion } \\
\text { feature number }\end{array}$ & \multicolumn{1}{c}{ Criterion features } \\
\hline \multirow{4}{*}{ Price } & 1.1 & price compared with the competition \\
\cline { 2 - 3 } & 1.2 & supply crediting (payment terms) \\
\cline { 2 - 3 } & 1.3 & transport costs \\
\hline \multirow{4}{*}{ Delivery time } & 1.4 & readiness to negotiate prices \\
\cline { 2 - 3 } & 2.1 & in-transit lead time \\
\cline { 2 - 3 } & 2.2 & delivery timeliness \\
\hline \multirow{4}{*}{ Quality } & 2.3 & readiness to carry out delivery on client's conditions \\
\cline { 2 - 3 } & 2.4 & distance from the supplier \\
\cline { 2 - 3 } & 3.1 & technical quality \\
\cline { 2 - 3 } & 3.2 & manufacturing norms \\
\cline { 2 - 3 } Additional features & 3.3 & quality of customer service \\
\cline { 2 - 3 } & 3.4 & number of complaints \\
\cline { 2 - 3 } & 4.1 & the supplier keeping stock \\
\cline { 2 - 3 } & 4.2 & supplier's potential \\
\hline
\end{tabular}

Source: own elaboration based on data from the Centrum Projekcji Multimedialnych company

towards making deliveries as requested by the client. The quality criterion is specified with the following features: the technical quality of materials and meeting the manufacturing norms related to the former (proved with certificates). Additionally, quality is extended by the following parameters: quality of customer service and number of complaints that demonstrate the quality of services rendered by the supplier. The quality of customer service is understood as the number of fulfilled orders in relation to the total number of orders. It hence allows to measure the supplier's ability to react to the special requirements of the clients.

\subsection{Supplier Partnership Assessment}

Examples of assessment scales for the two most significant supplier assessment and selection criteria, i.e. 1.1 price in comparison with competition and 2.1 in-transit lead time (cf. Tab. 2), which are used in scoring, are provided in Tabs. 3 and 4.

\section{Tab. 3: Supplier scoring rules: criterion 1.1 (price compared with the competition)}

\begin{tabular}{l|l|c|c}
$\begin{array}{c}\text { Feature } \\
\text { number }\end{array}$ & \multicolumn{1}{|c|}{ Scoring method } & $\begin{array}{c}\text { Scoring I } \\
\text { [points] }\end{array}$ & $\begin{array}{c}\text { Scoring II } \\
\text { [points] }\end{array}$ \\
\hline \multirow{4}{*}{1.1} & supplier offers prices more than 5\% lower than average & 8 & 5 \\
\cline { 2 - 4 } & supplier offers prices up to 5\% lower than average & 6 & 4 \\
\cline { 2 - 4 } & supplier offers average prices & 4 & 3 \\
\cline { 2 - 4 } & supplier offers prices up to 5\% higher than average & 2 & 2 \\
\cline { 2 - 4 } & supplier offers prices more than 5\% higher than average & 0 & 1 \\
\hline
\end{tabular}

Source: own elaboration based on data from the Centrum Projekcji Multimedialnych company Note: Scoring I and II as described in section 3.1. 


\section{Tab. 4: Supplier scoring rules: criterion 2.1 (in-transit lead time)}

\begin{tabular}{c|l|c|c|c}
$\begin{array}{c}\text { Feature } \\
\text { number }\end{array}$ & \multicolumn{1}{|c|}{ Scoring method } & $\begin{array}{c}\text { Scoring I } \\
\text { [points] }\end{array}$ & $\begin{array}{c}\text { Scoring II } \\
\text { [points] }\end{array}$ \\
\hline \multirow{3}{*}{2.1} & 1 day & 3 days & 6 & 5 \\
\cline { 2 - 5 } & 7 days & 4 & 4 \\
\cline { 2 - 5 } & 14 days & 2 & 3 \\
\hline
\end{tabular}

Source: own elaboration based on data from the Centrum Projekcji Multimedialnych company

Note: Scoring I and II as described in section 3.1.

Tab. 5: The results of supplier assessment through scoring: price

\begin{tabular}{|c|c|c|c|c|c|c|}
\hline Criterion & Criterion features & $\begin{array}{l}\text { Criterion weighing } \\
\text { factor [\%] }\end{array}$ & Supplier & $\begin{array}{l}\text { Scoring I } \\
\text { [points] }\end{array}$ & Supplier & $\begin{array}{l}\text { Scoring II } \\
\text { [points] }\end{array}$ \\
\hline \multirow{4}{*}{ Price } & $\begin{array}{l}\text { 1.1. price compared } \\
\text { with the } \\
\text { competition }\end{array}$ & \multirow{4}{*}{30} & $\begin{array}{l}\text { A } \\
B \\
C \\
D \\
E \\
F\end{array}$ & $\begin{array}{l}4 \\
2 \\
6 \\
2 \\
4 \\
4\end{array}$ & $\begin{array}{l}\text { A } \\
B \\
C \\
D \\
E \\
F\end{array}$ & $\begin{array}{l}3 \\
2 \\
4 \\
2 \\
3 \\
3\end{array}$ \\
\hline & $\begin{array}{l}\text { 1.2. supply crediting } \\
\text { (payment terms) }\end{array}$ & & $\begin{array}{l}\text { A } \\
B \\
C \\
D \\
E \\
F\end{array}$ & $\begin{array}{l}0 \\
2 \\
6 \\
0 \\
2 \\
4\end{array}$ & $\begin{array}{l}\text { A } \\
B \\
C \\
D \\
E \\
F\end{array}$ & $\begin{array}{l}1 \\
2 \\
5 \\
1 \\
2 \\
4\end{array}$ \\
\hline & 1.3. transport costs & & $\begin{array}{l}A \\
B \\
C \\
D \\
E \\
F\end{array}$ & $\begin{array}{l}4 \\
4 \\
0 \\
0 \\
4 \\
0\end{array}$ & $\begin{array}{l}A \\
B \\
C \\
D \\
E \\
F\end{array}$ & $\begin{array}{l}5 \\
5 \\
1 \\
1 \\
5 \\
1\end{array}$ \\
\hline & $\begin{array}{l}\text { 1.4. readiness to } \\
\text { negotiate prices }\end{array}$ & & $\begin{array}{l}A \\
B \\
C \\
D \\
E \\
F\end{array}$ & $\begin{array}{l}2 \\
2 \\
2 \\
0 \\
2 \\
0\end{array}$ & $\begin{array}{l}A \\
B \\
C \\
D \\
E \\
F\end{array}$ & $\begin{array}{l}3 \\
3 \\
3 \\
1 \\
3 \\
1\end{array}$ \\
\hline
\end{tabular}

Source: own elaboration based on data from the Centrum Projekcji Multimedialnych company

Note: Scoring I and II as described in section 3.1.

Tabs. 5-9 show the results of the supplier assessment and the selection method under analysis. Owing to varied and complex calculation methodology, the adopted methods produce highly authoritative results. Tabs. 5-9 indicate that different results were obtained through the adoption of two scoring options: the arithmetic mean (scoring I) and the weighted average (scoring II).

With the first scoring method, supplier E obtained the highest arithmetic mean, whereas supplier D - the lowest; with the weighted 
Tab. 6: The results of supplier assessment through scoring: delivery time

\begin{tabular}{|c|c|c|c|c|c|c|}
\hline Criterion & Criterion features & $\begin{array}{c}\text { Criterion weighing } \\
\text { factor [\%] }\end{array}$ & Supplier & $\begin{array}{l}\text { Scoring I } \\
\text { [points] }\end{array}$ & Supplier & $\begin{array}{l}\text { Scoring II } \\
\text { [points] }\end{array}$ \\
\hline \multirow{4}{*}{$\begin{array}{l}\text { Delivery } \\
\text { time }\end{array}$} & $\begin{array}{l}\text { 2.1. in-transit lead } \\
\text { time }\end{array}$ & \multirow{4}{*}{28} & $\begin{array}{l}\text { A } \\
B \\
C \\
D \\
E \\
F\end{array}$ & $\begin{array}{l}2 \\
2 \\
4 \\
4 \\
2 \\
4\end{array}$ & $\begin{array}{l}A \\
B \\
C \\
D \\
E \\
F\end{array}$ & $\begin{array}{l}2 \\
2 \\
4 \\
4 \\
2 \\
4\end{array}$ \\
\hline & $\begin{array}{l}\text { 2.2. delivery } \\
\text { timeliness }\end{array}$ & & $\begin{array}{l}\text { A } \\
B \\
C \\
D \\
E \\
F\end{array}$ & $\begin{array}{l}2 \\
4 \\
4 \\
4 \\
4 \\
2\end{array}$ & $\begin{array}{l}A \\
B \\
C \\
D \\
E \\
F\end{array}$ & $\begin{array}{l}2 \\
4 \\
4 \\
4 \\
4 \\
2\end{array}$ \\
\hline & $\begin{array}{l}\text { 2.3. readiness to } \\
\text { carry out delivery } \\
\text { on client's } \\
\text { conditions }\end{array}$ & & $\begin{array}{l}A \\
B \\
C \\
D \\
E \\
F\end{array}$ & $\begin{array}{l}0 \\
2 \\
2 \\
2 \\
2 \\
2\end{array}$ & $\begin{array}{l}A \\
B \\
C \\
D \\
E \\
F\end{array}$ & $\begin{array}{l}1 \\
5 \\
5 \\
5 \\
5 \\
5\end{array}$ \\
\hline & $\begin{array}{l}\text { 2.4. distance from } \\
\text { the supplier }\end{array}$ & & $\begin{array}{l}A \\
B \\
C \\
D \\
E \\
F\end{array}$ & $\begin{array}{l}4 \\
6 \\
6 \\
0 \\
4 \\
0\end{array}$ & $\begin{array}{l}A \\
B \\
C \\
D \\
E \\
F\end{array}$ & $\begin{array}{l}3 \\
4 \\
5 \\
1 \\
5 \\
1\end{array}$ \\
\hline
\end{tabular}

Source: own elaboration based on data from the Centrum Projekcji Multimedialnych company

Note: Scoring I and II as described in section 3.1.

average, supplier D also scored the lowest, however, the best result was achieved not by supplier $\mathrm{E}$ but by supplier $\mathrm{C}$.

With the second scoring method, supplier E once again obtained the highest arithmetic mean while supplier F - the lowest; the lowest weighted average was obtained by supplier $D$ and the highest by supplier E.

Furthermore, the graphic method was adopted, which consists in presenting suppliers on a radar chart where the weaknesses and strengths of each are clearly presented. Fig. 1 and 2 show a comparison of the results of four selected suppliers in accordance with the adopted scoring method. The values in the figures increase along the radius and reach 0 in the centre of the circle and 5 on the edge. If the graphs reflecting the assessments of each supplier are joined, a geometric model characteristic of a supplier emerges. The perfect situation is when the model is circle-shaped.
A comparison of two best suppliers in terms of scoring I and scoring II allows to evaluate which of them is better in terms of a particular criterion (Fig. 1). Supplier E surpasses supplier $\mathrm{C}$ in terms of: transport costs -4 points (Tab. 5 , criterion 1.3), number of complaints -6 points (Tab. 7, criterion 3.4), keeping stock -4 points (Tab. 8, criterion 4.1), and potential -4 points (Tab. 8, criterion 4.2). In turn, supplier $C$ versus supplier $\mathrm{E}$ offers better prices -6 points (Tab. 5 , criterion 1.1), a longer period of supply crediting - 6 points (Tab. 5 , criterion 1.2), and a shorter in-transit lead time -4 points (Tab. 6 , criterion 2.1 ), thus it is better as far as features of great importance to the company are concerned. Therefore, despite the fact that supplier E had the highest arithmetic mean, it was not number one in the ranking based on the weighted average.

Similarly, we can draw conclusions from a comparison of the two weakest suppliers 
Tab. 7: The results of supplier assessment through scoring: quality

\begin{tabular}{|c|c|c|c|c|c|c|}
\hline Criterion & Criterion features & $\begin{array}{l}\text { Criterion weighing } \\
\text { factor [\%] }\end{array}$ & Supplier & $\begin{array}{l}\text { Scoring I } \\
\text { [points] }\end{array}$ & Supplier & $\begin{array}{l}\text { Scoring II } \\
\text { [points] }\end{array}$ \\
\hline \multirow{4}{*}{ Quality } & 3.1. technical quality & \multirow{4}{*}{32} & $\begin{array}{l}A \\
B \\
C \\
D \\
E \\
F\end{array}$ & $\begin{array}{l}4 \\
4 \\
4 \\
4 \\
4 \\
4\end{array}$ & $\begin{array}{l}A \\
B \\
C \\
D \\
E \\
F\end{array}$ & $\begin{array}{l}5 \\
5 \\
5 \\
5 \\
5 \\
5\end{array}$ \\
\hline & $\begin{array}{l}\text { 3.2. manufacturing } \\
\text { norms }\end{array}$ & & $\begin{array}{l}A \\
B \\
C \\
D \\
E \\
F\end{array}$ & $\begin{array}{l}2 \\
2 \\
2 \\
2 \\
2 \\
2\end{array}$ & $\begin{array}{l}A \\
B \\
C \\
D \\
E \\
F\end{array}$ & $\begin{array}{l}5 \\
5 \\
5 \\
5 \\
5 \\
5\end{array}$ \\
\hline & $\begin{array}{l}\text { 3.3. quality } \\
\text { of customer } \\
\text { service }\end{array}$ & & $\begin{array}{l}A \\
B \\
C \\
D \\
E \\
F\end{array}$ & $\begin{array}{l}2 \\
6 \\
6 \\
2 \\
6 \\
4\end{array}$ & $\begin{array}{l}A \\
B \\
C \\
D \\
E \\
F\end{array}$ & $\begin{array}{l}2 \\
4 \\
4 \\
3 \\
4 \\
3\end{array}$ \\
\hline & $\begin{array}{l}\text { 3.4. number } \\
\text { of complaints }\end{array}$ & & $\begin{array}{l}\mathrm{A} \\
\mathrm{B} \\
\mathrm{C} \\
\mathrm{D} \\
\mathrm{E} \\
\mathrm{F}\end{array}$ & $\begin{array}{l}6 \\
6 \\
4 \\
4 \\
6 \\
4\end{array}$ & $\begin{array}{l}\mathrm{A} \\
\mathrm{B} \\
\mathrm{C} \\
\mathrm{D} \\
\mathrm{E} \\
\mathrm{F}\end{array}$ & $\begin{array}{l}4 \\
4 \\
3 \\
3 \\
4 \\
3\end{array}$ \\
\hline
\end{tabular}

Source: own elaboration based on data from the Centrum Projekcji Multimedialnych company Note: Scoring I and II as described in section 3.1.

Tab. 8: The results of supplier assessment through scoring: additional features

\begin{tabular}{|c|c|c|c|c|c|c|}
\hline Criterion & Criterion features & $\begin{array}{c}\text { Criterion weighing } \\
\text { factor [\%] }\end{array}$ & Supplier & $\begin{array}{l}\text { Scoring I } \\
\text { [points] }\end{array}$ & Supplier & $\begin{array}{c}\text { Scoring II } \\
\text { [points] }\end{array}$ \\
\hline \multirow{3}{*}{$\begin{array}{l}\text { Additional } \\
\text { features }\end{array}$} & $\begin{array}{l}\text { 4.1. the supplier } \\
\text { keeping stock }\end{array}$ & \multirow{3}{*}{10} & $\begin{array}{l}\text { A } \\
B \\
C \\
D \\
E \\
F\end{array}$ & $\begin{array}{l}4 \\
5 \\
2 \\
4 \\
4 \\
2 \\
\end{array}$ & $\begin{array}{l}\text { A } \\
B \\
C \\
D \\
E \\
F\end{array}$ & $\begin{array}{l}5 \\
5 \\
3 \\
5 \\
5 \\
3 \\
\end{array}$ \\
\hline & $\begin{array}{l}\text { 4.2. supplier's } \\
\text { potential }\end{array}$ & & $\begin{array}{l}\text { A } \\
B \\
C \\
D \\
E \\
F\end{array}$ & $\begin{array}{l}4 \\
2 \\
2 \\
4 \\
4 \\
2\end{array}$ & $\begin{array}{l}A \\
B \\
C \\
D \\
E \\
F\end{array}$ & $\begin{array}{l}5 \\
3 \\
3 \\
5 \\
5 \\
3\end{array}$ \\
\hline & $\begin{array}{l}\text { 4.3. supplier's } \\
\text { image }\end{array}$ & & $\begin{array}{l}A \\
B \\
C \\
D \\
E \\
F\end{array}$ & $\begin{array}{l}4 \\
4 \\
4 \\
4 \\
4 \\
4 \\
4\end{array}$ & $\begin{array}{l}A \\
B \\
C \\
D \\
E \\
F\end{array}$ & $\begin{array}{l}5 \\
5 \\
5 \\
5 \\
5 \\
5\end{array}$ \\
\hline
\end{tabular}

Source: own elaboration based on data from the Centrum Projekcji Multimedialnych company Note: Scoring I and II as described in section 3.1 


\section{Business Administration and Management}

\section{Tab. 9: The final results of supplier assessment through scoring}

\begin{tabular}{l|c|c|c|c} 
Criterion & Supplier & $\begin{array}{c}\text { Scoring I } \\
\text { [points] }\end{array}$ & Supplier & $\begin{array}{c}\text { Scoring II } \\
\text { [points] }\end{array}$ \\
\hline Total number of points & A & 44 & A & 51 \\
& B & 53 & B & 58 \\
& C & 54 & C & 59 \\
& D & 36 & D & 50 \\
Arithmetic mean & F & 34 & E & 62 \\
& A & 2.93 & F & 48 \\
\hline Weighted average & C & 3.47 & B & 3.40 \\
& D & 3.73 & C & 3.87 \\
& E & 3.53 & D & 3.93 \\
& F & 2.87 & E & 4.13 \\
& A & 10.92 & F & 3.20 \\
\hline & C & 13.68 & B & 12.46 \\
& D & 15.16 & C & 14.86 \\
& E & 15.08 & D & 15.48 \\
& F & 9.92 & E & 12.04 \\
\hline
\end{tabular}

Source: own elaboration based on data from the Centrum Projekcji Multimedialnych company

Note: Scoring I and II as described in section 3.1. The best suppliers are indicated bold; the worst suppliers are indicated in italics.

\section{Fig. 1: Suppliers with the highest and lowest results obtained in scoring (scoring I)}

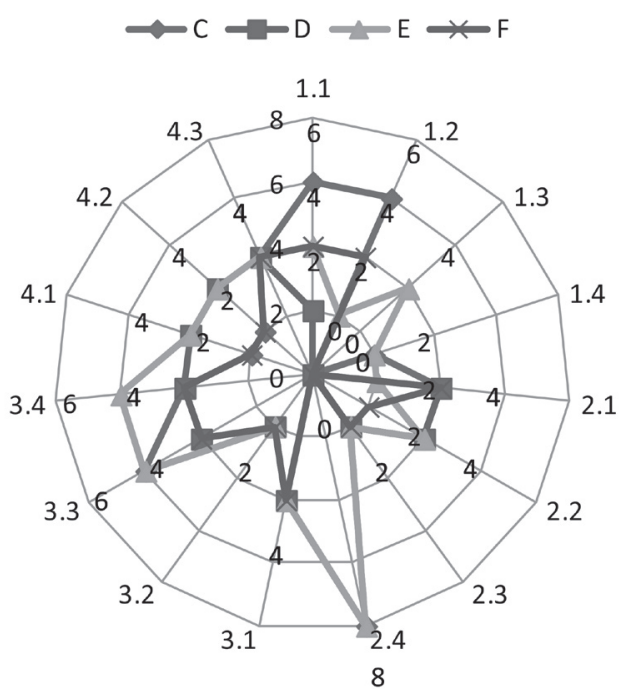

Source: own elaboration based on data from the Centrum Projekcji Multimedialnych company Note: Scoring I and II as described in section 3.1. 


\section{Fig. 2: Suppliers with the highest and lowest results obtained in scoring (scoring II)}

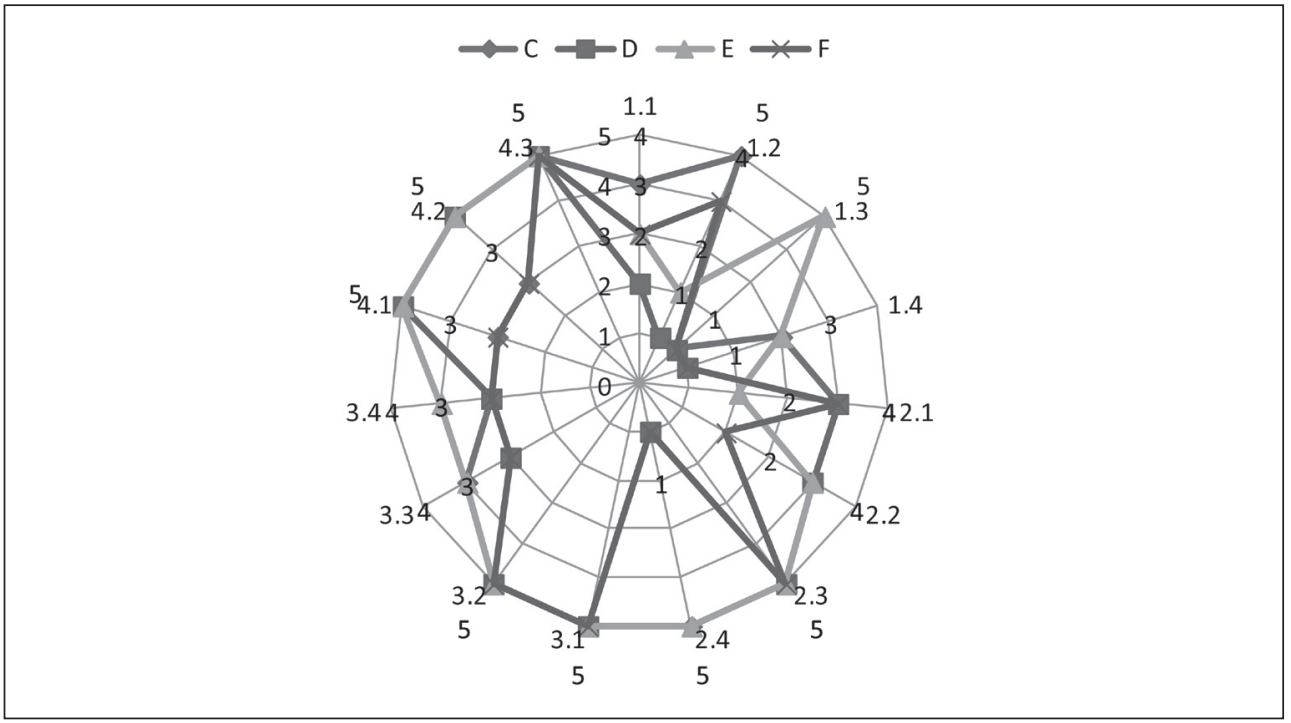

Source: own elaboration based on data from the Centrum Projekcji Multimedialnych company

Note: Scoring I and II as described in section 3.1.

(suppliers $D$ and $F$ ). In spite of the fact that both suppliers had the same number of points, supplier $\mathrm{D}$ scored the lowest in estimation based on the weighted average. This fact is explained with the circle model (Fig. 1), which shows that the supplier obtained higher scores in categories that are of smaller significance for company $D$ against supplier $F$ (keeping stock -4 points, Tab. 8, criterion 4.1; potential -4 points, Tab. 8, criterion 4.2) and low for the properties of huge importance (price -2 points, Tab. 5, criterion 1.1; supply crediting -0 points, Tab. 5 , criterion 1.2 ).

If the second scoring method is adopted, a perfect supplier is represented by a circle with a 5-point radius since it is the highest score in each category. Analysing the circle model generated through the use of this scoring method (Fig. 2), one may conclude that indeed supplier $\mathrm{E}$ is represented by an extent and graph that are the closest to a circle. It is more difficult, however, to indicate the supplier with the lowest extent.

Data in Fig. 2 allow to conclude that the proportions between the strongest and the weakest supplier are smaller than those indicated by scoring I.
Another method used in the company was the AHP method. This method served to compare decision variants. It seems advisable to use such a method for selecting multimedia projection centre's suppliers, especially when the decision taken has a strategic significance.

Suppliers were assessed on the basis of data presented in Tab. 10. Data reflecting criteria 1, 4, 6, 7 were obtained from the company's statistics. The matrix of criteria priority and the matrix of standardized values, derived from the former, allowed to determine the weighing factors for all criteria (Tab. 11).

As a result of six iterations in relation to each criterion, the above results were obtained. The final ranking of variants was calculated on the basis of the multiplication of the obtained matrix and the matrix of criteria validity.

From the point of view of the selected criteria, supplier $C$ is the best one as its multicriteria preference index was the highest and equal to 0.37 (Tab. 12). Supplier $D$ was the one that had the lowest index, which amounted to 0.08. As it turned out, the three most significant criteria were: price, quality of service, and supply crediting. As far as two of these criteria 


\section{Business Administration and Management}

Tab. 10: Supplier assessment criteria in the AHP method
No.

Source: own elaboration based on data from the Centrum Projekcji Multimedialnych company

\begin{tabular}{|c|c|c|c|c|c|c|c|}
\hline \multirow{3}{*}{ Suppliers } & \multicolumn{7}{|c|}{ Criteria } \\
\hline & 1 & 2 & 3 & 4 & 5 & 6 & 7 \\
\hline & $\min$ & $\max$ & $\min$ & $\max$ & $\min$ & $\min$ & $\max$ \\
\hline A & $0 \%$ & 0 & 7 & $95.00 \%$ & 230 & $4.00 \%$ & $92.00 \%$ \\
\hline B & $3 \%$ & 7 & 4 & $98.40 \%$ & 170 & $3.00 \%$ & $95.60 \%$ \\
\hline C & $-5 \%$ & 30 & 3 & $97.80 \%$ & 130 & $6.00 \%$ & $95.20 \%$ \\
\hline$D$ & $5 \%$ & 0 & 4 & $99.00 \%$ & 490 & $5.50 \%$ & $93.10 \%$ \\
\hline $\mathrm{E}$ & $1 \%$ & 7 & 5 & $98.10 \%$ & 145 & $2.50 \%$ & $96.30 \%$ \\
\hline $\mathrm{F}$ & $2 \%$ & 14 & 4 & $95.50 \%$ & 415 & $6.50 \%$ & $93.50 \%$ \\
\hline
\end{tabular}

Source: own elaboration based on data from the Centrum Projekcji Multimedialnych company

\section{Tab. 12: Multi-criteria ranking: juxtaposition of the results}

\begin{tabular}{c|c|c|c|c|c|c|c|c} 
Suppliers & Price & Credit & $\begin{array}{c}\text { In-transit } \\
\text { lead time }\end{array}$ & Timeliness & Distance & Complaints & Service & $\begin{array}{c}\text { AHP method } \\
\text { results }\end{array}$ \\
\hline A & 0.18 & 0.04 & 0.003 & 0.03 & 0.14 & 0.17 & 0.03 & 0.10 \\
\hline B & 0.06 & 0.09 & 0.170 & 0.34 & 0.19 & 0.29 & 0.25 & 0.15 \\
\hline C & 0.53 & 0.54 & 0.040 & 0.12 & 0.30 & 0.04 & 0.18 & 0.37 \\
\hline D & 0.03 & 0.04 & 0.170 & 0.31 & 0.02 & 0.06 & 0.06 & 0.08 \\
\hline E & 0.12 & 0.09 & 0.070 & 0.16 & 0.30 & 0.41 & 0.42 & 0.02 \\
\hline F & 0.09 & 0.20 & 0.170 & 0.04 & 0.04 & 0.03 & 0.06 & 0.09 \\
\hline
\end{tabular}

Source: own elaboration based on data from the Centrum Projekcji Multimedialnych company 
are concerned, supplier $\mathrm{C}$ took the first place in the preference ranking and supplier $\mathrm{D}$ - the last place. It may thus be concluded that these very categories determined the place of a supplier in the general ranking.

The results obtained with the AHP method were consistent with those of scoring with the weighted average and scoring method I. In both cases, supplier $C$ was the best and supplier D the worst option. The implementation of the AHP method in the supplier selection process was quite successful. The AHP results also provided a solid reference framework for choosing the right supplier/suppliers. This approach was easy to apply, but it required much effort in its extensive calculations.

To sum up, the use of scoring based on the weighted average offers reliable results while it is not particularly labour-intensive at the same time. Nevertheless, it is worth using a more sophisticated method once in a while in order to verify whether the suppliers that provide the company with supplies continue to lead on the market. Applying the AHP method may also be useful if scoring does not produce clearcut results. It is also recommended to develop intervals on preference indices, which would divide suppliers into groups, e.g. preferred, acceptable, unacceptable suppliers.

\section{Discussion}

The proposed supplier partnership assessment model may be considered the fundamental element of the study. The presented model is the outcome of a literature review and an effect of interpreting the results of research carried out by a Polish trading company. It creates appropriate basis for setting out supplier selection conditions and simultaneously allows companies to make optimal choices.

Also, a high level of partnership allows to develop the competitiveness of an organization. It indicates the important role that stakeholders can play in the design, manufacturing, and development of products by providing knowledge and skills. A stronger integration of the organization with stakeholders helps strengthen the organization's marketing mix, gives better access to innovations, and facilitates entering new markets. Each party must be aware that it is through good cooperation and partnership that it can gain benefits. And good relationships between organizations and suppliers bring many benefits. They mainly allow to reduce costs related with service, which means that maintaining cooperation with existing stakeholders is much cheaper than searching for new ones. It is also possible to develop an individual offer for each stakeholder by implementing them in the production process.

Negotiating lower prices for products delivered by the supplier enables the company to reduce its inputs, which at the same time means that the supplier reduces its obtained effects of selling a unit of the product. In turn, increased effects achieved by the supplier as a result of negotiating higher prices for their offered products mean an increase in expenditures incurred by the customer in relation to the supply of products.

Reducing the number of suppliers is an evident process; even if more suppliers are qualified, the greatest burden of delivery falls on one or two of them. In turn, close contacts and long-term relationships also help reduce costs, e.g. through price negotiations or additional discounts and free of charge offers.

It should be emphasized that choosing the right supplier and maintaining proper relationship with them is an extremely important component of a company's strategy. The decision concerning supplier choice depends mainly on quality and price. A suitably selected supplier and the product offered, linked to the timeliness and completeness of deliveries, as well as compliance with the pre-established rules, can constitute a very significant factor for any smaller or larger company.

\section{Conclusions}

The authors hope that the content of this article may prove useful in conducting further research on partnership with suppliers. It will obviously have a positive influence on the development of Polish and foreign science but will also widen the knowledge of managers, which may contribute to genuine market success of companies operating in Poland.

The results of supplier partnerships suggest that some criteria applicable to the company's suppliers are more significant than others, and that they are the ones which ought to underlie the system of such assessment. The presented supplier partnership assessment model allows to select suppliers that will provide best quality goods at the lowest price. 


\section{References}

Ashkenas, R., Ulrich, D., Jick, T., \& Kerr, S. (1995). The boundaryless organization: breaking the chains of organizational structure. San Francisco: Jossey-Bass Publishers.

Bouchbout, K., \& Alimazighi, Z. (2009). A framework for identifying the critical factors affecting the decision to adopt and use inter-organizational information systems. International Journal of Human and Social Sciences, 4(7), 509-516.

Christopher, M. (2000). Logistyka i zarządzanie łańcuchem dostaw. Warszawa: PCDL.

Emmett, S. (2012). Quick guide to supplier relationship management in the supply chain. Cambridge: Cambridge Academic.

Emmett, S., \& Crocker, B. (2009). Excellence in supplier management. How to better manage contracts with suppliers and add value. Best practices in supplier relationship. Management and supplier development. Cambridge: Cambridge Academic.

Kaczmarek, B. (2011). Menedżerowie jutra a wartość przedsiębiorstwa. Zeszyty Naukowe Uniwersytetu Szczecińskiego. Finanse, Rynki Finansowe, Ubezpieczenia, 685, 425-430.

Kale, P., \& Singh, H. (2009). Emerging multinationals: a partnering approach to acquisitions. In Strategic Management Society India Conference. Hyderabad, India.

Kawa, A. (2011). Konfigurowanie łańcucha dostaw. Poznań: Wydawnictwo Uniwersytetu Ekonomicznego w Poznaniu.

Lambert, D. M., \& Pohlen, T. L. (2001). Supply chain metrics. International Journal of Logistics Management, 12(1), 1-19. https://doi. org/10.1108/09574090110806190.

Laskowska-Rutkowska, A. (2014). Cechy proinnowacyjnych relacji w łańcuchu dostaw. Gospodarka Materiałowa i Logistyka, 2, 8-13.

Lorenzoni, G., \& Lipparini, A. (1999). The leveraging of interfirm relationships as a distinctive organizational capability: a longitudinal study. Strategic Management Journal, 20, 317-338. https://doi.org/10.1002/ (SICI)1097-0266(199904)20:4<317::AIDSMJ28>3.0.CO;2-3.

Matwiejczuk, R. (2014). Kompetencje logistyki w tworzeniu przewagi konkurencyjnej przedsiębiorstwa. Opole: Uniwersytet Opolski.
Mettler, T., \& Rohner, P. (2009). Supplier relationship management: a case study in the context of health care. Journal of Theoretical and Applied Electronic Commerce Research, 4(3), 58-71. https://doi.org/10.4067/S071818762009000300006.

Nenadál, J. (2006). Management partnerství $s$ dodavateli. Praha: Management Press.

Ocicka, B., \& Raźniewska, M. (2015). Rola budowania relacji partnerskich z kluczowymi dostawcami w zarządzaniu łańcuchem dostaw. Studia Ekonomiczne. Zeszyty Naukowe Uniwersytetu Ekonomicznego w Katowicach, 249, 63-75.

Poirer, C. C. (2012). Supplier Relationships Management (SRM): Virtual Networks. In J. B. Ayers (Ed.), Encyclopedia of supply chain management. Boca Raton: CRC Press Taylor \& Francis Group.

Provan, K. G., \& Kenis, P. N. (2007). Modes of network governance: structure, management, and effectiveness. Journal of Public Administration Research and Theory, 18(2), 229-252. https://doi.org/10.1093/jopart/ mum015.

Romanowska, M., \& Trocki, M. (2002). Przedsiębiorstwo partnerskie. Warszawa: Difin.

Ross, D. F. (2018). Distribution planning and control. Managing in the era of supply chain management (3rd ed.). New York: Springer.

Smith, K. G., Carroll, S. J., \& Ashford, S. J. (1995). Intra- and interorganizational cooperation: toward a research agenda. Academy of Management Journal, 38(1), 7-23.

Tyszkiewicz, R. (2017a). Identyfikacja znaczenia zarządzania relacjami z dostawcami w kształtowaniu konkurencyjności małych i średnich przedsiębiorstw przemysłu meblarskiego. Przegląd Organizacji, 4, 53-61.

Tyszkiewicz, R. (2017b). Zarządzanie relacjami z interesariuszami organizacji. Warszawa: Placet.

Urbaniak, M. (2008). Budowanie relacji partnerskich między dostawcami a klientami na rynku B2B. Logistyka, 3, 54-67.

Van Weele, A. (2014). Purchasing and supply chain management. Andover: Cengage Learning. 
Wen, X., Yan, M., Xian, J., Yue, R., \& Peng, A. (2015). Supplier selection in supplier chain management using Choquet integral-based linguistic operators under fuzzy heterogeneous environment. New York: Springer Science \& Business Media.

Wieteska, G. (2011). Rola ryzyka w budowaniu relacji $\mathrm{z}$ dostawcami. Acta Universitatis Lodziensis, Folia Oeconomica, 251, 235-261.
Rafał Tyszkiewicz, Ph.D.

WSB University

Faculty of Finance and Management

Poland

rafal.tyszkiewicz@wsb.wroclaw.pl

Ing. Agnieszka Pawlak-Wolanin, Ph.D. WSB University

Faculty of Finance and Management Poland agnieszka.pawlak_wolanin@wsb.wroclaw.pl

Ing. Julita Markiewicz-Patkowska, Ph.D. WSB University

Faculty of Finance and Management Poland julita.markiewicz-patkowska@wsb.wroclaw.pl

Assoc. Prof. Soňa Jandová, Ph.D. Technical University of Liberec Faculty of Mechanical Engineering Czech Republic sona.jandova@tul.cz

Assoc. Prof. Piotr Oleśniewicz, Ph.D. University School of Physical Education in Wrocław Faculty of Physical Education Poland piotr.olesniewicz@awf.wroc.pl

PhDr. Ing. Helena Jáčová, Ph.D. Technical University of Liberec Faculty of Economics Czech Republic helena.jacova@tul.cz

Monika Tyszkiewicz, MSc WSB University Faculty of Finance and Management Poland monika.tyszkiewicz@wsb.wroclaw.pl 


\section{Abstract}

\section{INNOVATIVE SUPPLIER PARTNERSHIP ASSESSMENT MODEL IN A POLISH TRADING ENTERPRISE}

\section{Rafał Tyszkiewicz, Agnieszka Pawlak-Wolanin, Julita Markiewicz-Patkowska, Soňa Jandová, Piotr Oleśniewicz, Helena Jáčová, Monika Tyszkiewicz}

The relationship between a company and a supplier is a strategic resource for both parties. Therefore, the necessity to develop a mechanism of an integrated approach to cooperation with suppliers, which is based on partnership, is becoming more and more pronounced. Such an approach necessitates taking into consideration an abundance of factors accompanying cooperation within a mutual venture. These factors may include: compatibility of businesses - similar values, organizational cultures, and goals or the philosophy and management methods. The objective of the article is to present a supplier partnership assessment model as implemented in a Polish trading enterprise, as well as proposed assessment criteria and methods. Verification of the criteria applied to suppliers has been performed on the example of Centrum Projekcji Multimedialnych, which is a dealer of the following companies: inFocus, Sony, Sanyo, Toshiba, Epson, Panasonic, and 3M. Operational data of the company have been used for that purpose; in turn, the assessment and selection of the key suppliers took place through the use of the following methods: $A B C$ analysis, scoring, the graphics method, and the Analytic Hierarchy Process method. Out of 18 suppliers that the company cooperates with on an ongoing basis, six key ones were selected. The results of supplier partnerships suggest that some criteria applicable to the company's suppliers are more significant than others, and that they are the ones which ought to underlie the system of such assessment. The presented supplier partnership assessment model allows selecting suppliers that will be providing best quality goods at the lowest price.

Key Words: Supplier assessment, partnership, supplier selection method.

JEL Classification: L17, M19, O31.

DOI: 10.15240/tul/001/2019-3-005 